\title{
REVIEW OF RESEARCH IN LEARNING ENVIRONMENT
}

\author{
Jamaiah I' \\ 'Department of Parasitology, Faculty of Medicine, University of Malaya, 50603 Kuala Lumpur, Malaysia
}

\begin{abstract}
:
Educational environment of an institution is the environment experienced or perceived by students and teachers. Individual students and teachers will respond differently to these subtle elements in their learning experience. Curriculum's most significant manifestation and conceptualisation is the environment. There is a proven connection between the environment and the valuable outcomes of students' achievement, satisfaction and success. If one wants to describe, assess or get a handle on the curriculum in a medical school, then the educational and organisational environment or total milieu associated with the curriculum and the medical school needs to be studied. Educational environment is one of the most important determinants of an effective curriculum. Educational environment fosters scholarly or intellectual activities; it encourages friendliness, co-operation and supportiveness. It also fosters the learning, growth and development of students. Students' perceptions of their educational environment are a useful basis for modifying and improving the quality of educational environment. Several research groups over the years have attempted to identify and quantify the presence and impact of rather intangible aspects of a learning environment. Each study has used different survey questionnaires to solicit student reactions. (JUNMEC 2008; 11 (1): 7-11)
\end{abstract}

KEYWORDS: Learning environment, curriculum, climate, medical school

\section{Introduction}

\section{What is Learning Environment?}

Learning environment or 'climate', 'ethos', 'ambiance' and 'atmosphere' of an institution is the environment experienced or perceived by students and teachers. Individual students and teachers will respond differently to these subtle elements in their learning experience. An educational environment has a 'personality'; studying this unique personality enables faculty, administrators and students to answer the main question, "What is medical education here really like?" Climate could easily be judged as a somewhat vague and ethereal concept. The climate of an educational environment, like the concept itself, is rather intangible, unreal and insubstantial, yet climate, in its effects, is pervasive, substantial and very real and influential (I).

Genn (200I) explained educational environment as follows:

“Curriculum's most significant manifestation and conceptualization is the environment, educational and organizational, which embraces everything that is happening in the medical school. There is a proven connection between the environment and the valuable outcomes of students' achievement, satisfaction and success. If one wants to describe, assess or get a handle on the curriculum in a medical school, then the educational and organizational environment or total milieu associated with the curriculum and the medical school needs to be studied. Educational environment is one of the most important determinants of an effective curriculum.” (2)

"The university is a habitat, a society, a community, an environment, an ecosystem. It should be judged by the quality of life that it fosters, the opportunities for growth and experiment and exploration it provides, the concern for growth and enrichment and for culture that it exemplifies. The question is not just: 'What does your machine produce?' but also: "How does the garden grow?" (3).

Educational environment/climate can be divided into three parts (4):

I. The physical environment (facilities, comfort, safety, food and accommodation)

2. The emotional climate (security, positive methods and reinforcement)

3. The intellectual climate (learning with patients, follow-through, evidence-based and up-to-date knowledge and skills)

Correspondence:

Jamaiah l.

Department of Parasitology,

Faculty of Medicine,

University of Malaya,

50603 Kuala Lumpur, Malaysia 


\section{Why is Learning Environment important?}

The General Medical Council (GMC) has initiated major innovations in the undergraduate medical curriculum and improvement of the learning environment is one of the major goals of the changes (5).

The United Kingdom (UK) Standing Committee on Postgraduate Medical Education stated that:

"A working environment that is conducive to learning is critically important to successful training." (6)

Entwistle (1995) explained that: "Learning is a process that is not easy to comprehend. Learning is influenced by the way in which the student goes about learning and studying as well as the conduciveness of the learning environment." (7)

Besides having a beautiful, modern and up-to-date infrastructure, a school or institution of higher learning must also have a modern and up to date learning environment. Emotional and social conditions of the institution which make up the psychological environment are extremely important because these affect the well being of the students and also the staff of the institution or universities. A calm and supportive environment is an essential prerequisite for successful learning. It was reported that students who perceived their learning environment as positive are more likely to develop effective learning strategies. Satisfaction with learning environment can encourage desirable approaches to learning - deep learning - vice versa (8).

Students' perceptions of their educational environment are a useful basis for modifying and improving the quality of educational environment. Continuous quality improvement and innovation are very essential in a medical school (9).

Educational environment research has shown that there is a high price to be paid for a dysfunctional learning environment. The adverse effects include stress, academic failure and dropout, and the cultivation of undesirable behaviour and attitudes. The potential benefits of an enhanced educational environment include comfort, confidence, responsibility, skills, knowledge, reinforcement, learning opportunities and models for practice (I0).

Educational climate strongly affects student achievement, satisfaction and success. It is important to get regular feedback from students on how they experience the educational environment. Information obtained will provide a useful basis for strategic planning and resource utilization. Institutional remedial action should follow student's indication of areas of concern (II).

\section{Research that has been done on learning environment}

Several research groups over the years have attempted to identify and quantify the presence and impact of rather intangible aspects of a learning environment. Each study has used different survey questionnaires to solicit student reactions.

In order to develop an environment that is conducive to learning there are two prerequisites. One, what are the major elements that contribute to the particular learning environment? Two, what is the best available instrument that is needed to measure the learning environment to allow accurate assessment of the learning environment and to identify those areas that require immediate attention? The same instrument could subsequently be used to monitor the effect that any changes implemented have made.

Research began in 1930s with an interest in educational environment. Pace and Stern in 1958 developed an instrument to study educational environment by developing the MEI (Medical Environment Index) (I2).

Levy et al (1973) surveyed the learning environment in a Georgia Medical School in the context of assessing curriculum change. Dimensions measured are desirability of learning situation, academic enthusiasm, goal direction, authoritarianism, breadth of interest, student interaction, and intellectual maturity (I3).

Marshall in 1978 developed the MSLES (50-item) (Medical Schools Learning Environment Survey) to measure aspects of the learning environment relevant to student stress. Analysis from first administration to 93 first-year students at the Chicago Medical School indicated acceptable levels of reliability and validity (14).

Huebner (198I) designed and used the Medical School Environmental Stress Inventory (6I-item) (MSESI) to measure student-reported stress. A total of 220 students at the University of Missouri-Columbia School of Medicine completed the questionnaire. Students described the major stressors as information - input overload, shortage of time, inadequate feedback regarding performance, and poor quality of interpersonal relationships (I5).

Moore-West et al (1989) compared the perceptions of distress and attitudes toward the learning environment of students in innovative curricula and the traditional curricula using the Symptom questionnaire (SQ) and the Learning Environment Questionnaire (LEQ). The $\mathrm{SQ}$ was designed to measure dimensions of perceived 
distress and the LEQ evolved from Marshall's medical School Environment Inventory consists of 5 subscales (I. The emotional climate subscale, 2 . The nurturance subscale, 3. The student-student interaction, 4 . The meaningful learning experience, 5. The flexibility subscale measuring an individual's perception of the learning environment). She found that the innovativetrack students' perceptions of distress were significantly lower than those of the traditional-track students. Their expectations and perceptions of the learning environment were more positive, and they found their curriculum more meaningful and flexible than did traditional-track students. These findings suggest that a student-centered, problem-based approach may more effectively help students handle the stress associated with mastering a large body of information and coping with distressing situations such as those encountered by the practising physician (16).

Strayhorn and Frierson (1989) conducted a longitudinal study of first-year medical students at the University of North Carolina (UNC) School of Medicine to assess the correlations between the students' perceptions of the medical school learning environment and both their academic performances and their perceptions of well being using the 99-item questionnaire. They found that both the black and white students had similar perceptions of the learning environment's quality. Black students experienced more stress but found more support from faculty, class advisors, and administrators (I7).

Mosley et al (1994) used the Medical Education Hassles Scale-R to assess stress, Coping Strategies Inventory (CSI) (85-items) to assess coping thoughts and behaviours in response to stress, Center for Epidemiologic Studies-Depression scale (CES-D) to assess well-being, and the Wahler Physical Symptoms Inventory (WPSI) to measure somatic complaints to 69 third-year students completing a psychiatry clerkship at the University of Mississippi School of Medicine. They reported that clinical level of depression was found in $23 \%$ of the students (18).

Dunn and Burnett (1995) used the Clinical Learning Environment (CLE) scale (23-items) to identify factors that characterize a clinical learning environment. This instrument has five subscales: staff-student relationships, nurse manager commitment, patient relationships, interpersonal relationships and student satisfaction. This scale provides the educator with a valid and reliable instrument to evaluate relevant factors in the CLE, direct resources to areas where improvement may be required, and nurture those areas functioning well (19).
The Center for Medical Education (CME) in Dundee, Scotland has developed an instrument or a diagnostic tool to assess learning environment. It is called the The Dundee Ready Education Environment Measure (DREEM). It is a very useful and flexible tool in that it is not culturally specific and can be used in a wide range of health professions institutions. It has been validated and tested in a range of settings and has proved to be a very useful 'diagnostic tool'. The (DREEM) instrument is a robust, 'culture free' and renowned tool which measure the quality of the educational environment and has been used by many researchers masters and doctoral students for the study of learning environment in their institutions (20-27). It has been validated and tested and has proven to be a very useful and easy to apply tool. Table I summaries the research utilising the DREEM as a diagnostic tool for the educational environment.

Sobral (2004) used the Course Valuing Inventory (CVI) to appraise how medical students perceive the meaning and value of their first-year experiences in medical studies and to identify the relationship between the CVI responses and the learners' attributes and expectations. The study involved 282 second-year students of a six-year medical programme over a fouryear time frame (University of Brasilia, Brasilia, Brazil). Higher CVI scores related positively and significantly to female gender, stronger self-confidence as a learner, greater motivation to learn, meaningful orientation and reflection in learning. A separate test done showed that there was a significant relationship between the dimensions of $\mathrm{CVI}$ responses and the DREEM score (30).

\section{Conclusion}

Positive learning environment must be maintained and nurtured. In a supportive learning environment, the teacher encourages independence with learning, promotes critical thinking, promotes students' freedom to explore, and accepts differences among students in their approaches to solving problems. Regular evaluation and feedback will provide further valuable input for institution strategic planning. Institutional resources can be focused on those areas that urgently require remedial actions. Medical Schools must inculcate in our students the benefit $s$ of lifelong learning and critical thinking. 
Table I summarises the research utilising the DREEM as a diagnostic tool for the educational environment

\begin{tabular}{|c|c|c|c|}
\hline No & Medical Institutions/Schools & Students surveyed & $\begin{array}{l}\text { Total Mean Score } \\
\text { (Reference) }\end{array}$ \\
\hline $\mathrm{I}$ & UK Medical Schools & Undergraduate medical students & $132 / 200(6)$ \\
\hline 2 & $\begin{array}{l}\text { Arab Gulf University } \\
\text { Arab United Emirates University }\end{array}$ & & $\mid 27 / 200,125 / 200(2 \mid)$ \\
\hline 3 & Nigerian Medical School & $\begin{array}{l}\text { Undergraduate medical students } \\
\text { (Years } 4,5 \text { \& } 6)\end{array}$ & $1 \mathrm{I} / 200(22)$ \\
\hline 4 & Nepalese Health Professions & $\begin{array}{l}\text { Undergraduate medical students } \\
\text { (Years I, } 2 \text { \& 3) }\end{array}$ & $130 / 200(22)$ \\
\hline 5 & $\begin{array}{l}\text { University of Sao Paulo School of Medicine } \\
\text { Faculty of Medical Sciences in Trinidad }\end{array}$ & First-Year medical students & I24.4/200 (28) \\
\hline 6 & Kasturba Medical College, India & Clinical years medical students & $107.4 / 200(29)$ \\
\hline 7 & $\begin{array}{l}\text { Canadian Memorial Chiropractic College } \\
\text { (CMCC) Toronto, Canada }\end{array}$ & $\begin{array}{l}\text { First, second and third year } \\
\text { students }\end{array}$ & I I 3/200 (27) \\
\hline 8 & $\begin{array}{l}\text { Medical School at King Abdul Aziz } \\
\text { University; } \\
\text { Saudi Arabia Umm Al-Qura University, } \\
\text { Saudi Arabia; } \\
\text { Sana'a University, Republic of Yemen; } \\
\text { Dundee University Medical School, } \\
\text { Scotland }\end{array}$ & Undergraduate medical students & $\begin{array}{l}102 / 200 \\
107 / 2001 \\
100 / 2001 \\
139 / 200(25)\end{array}$ \\
\hline 9 & $\begin{array}{l}\text { Faculty of Medicine, University of Brasilia, } \\
\text { Brazil }\end{array}$ & Second year medical students & $123 / 200(30)$ \\
\hline 10 & Dental Training College, Malaysia & $\begin{array}{l}\text { Dental nursing and dental } \\
\text { Technology first and second } \\
\text { year students }\end{array}$ & $122 / 200(6 \mid \%)(26)$ \\
\hline II & Birmingham University, England & Final year medical students & $139 / 200(70 \%)(31)$ \\
\hline 12 & $\begin{array}{l}\text { Faculty of Medical Sciences, University of } \\
\text { Sri Jayewardenepura, Sri Langka }\end{array}$ & $\begin{array}{l}\text { Pre-clinical, para-clinical year } \\
\text { medical students }\end{array}$ & $108 / 200(32)$ \\
\hline
\end{tabular}

DREEM $=$ The Dundee Ready Education Environment Measure

\section{References}

I. Genn JM, Harden RM. What is medical education here really like? Suggestions for action research studies of climates of medical education environments. Med Teacher 1986; 8(20): I I I-I 24.

2. Roff S, McAleer S. What is educational climate? Med Teacher 200I; 23(4): 333-334.

3. Genn JM. AMEE Medical Education Guide No. 23(part I): Curriculum, environment, climate, quality and change in medical education-a unifying perspective, Med Teacher 200I; 23(4):337-344.

4. Pace CR. Thoughts on Evaluation in Higher Education, lowa City: The American College Testing Program; 197I.

5. Wall D. Educational Concepts: The theory behind the practical aspects of Teaching and Learning, in: Chambers, R \& Wall, D. Teaching Made Easy: A Manual for Health Professionals. Oxford: Radcliffe Medical Press Ltd; 2000.

6. Roff S, McAleer S, Harden RM, et al. Development and validation of the Dundee Ready Education 
environment measure (DREEM), Med Teacher 1997; 19(4): 295-299.

7. Standing Committee on Postgraduate Medical Education (SCOPME), Good Practice in SHO training; |99|.

8. Entwistle NJ. Supporting Effective learning: A Research Perspective. Edinburgh: Centre for Research on Learning and Instruction, University of Edinburgh; 1995.

9. Pimparyon P, Roff S, McAleer S, et al. Educational environment, student approaches to learning and academic achievement in a Thai nursing school. Med Teacher 2000; 22(4):359-365.

10. Mulrooney A. Development of an instrument to measure the Practice Vocational Training Environment in Ireland. Med Teacher 2005; 27(4):338-342.

II. Till H. Climate studies: can students perceptions of the ideal educational environment be of use for institutional planning and resource utilization? Med Teacher 2005; 27(4):332-337.

12. Pace CR, Stern GG. An approach to the measurement of the psychological characteristics of college environments. J Educ Psychol 1958; 49(5):269-277.

13. Levy M, Morse PK, Liebelt RA et al. Use of the learning environment questionnaire to assess curriculum change. J Med Educ 1973; 48:840440.

14. Marshall RE. Measuring the medical school learning environment.J Med Educ 1978; 53(2):98-104.

15. Huebner LA, Royer JA, Moore J. The assessment and Remediation of dysfunctional Stress in medical school, J Med Educ 198I; 56:547-558.

16. Moore-West M, Harrington DL, Mennin SP et al. Distress and attitudes toward the learning environment: effects of a curriculum innovation. Teaching and Learning In Medici, I989; I(3): I5I157.

17. Strayhorn G, Frierson H. Assessing correlations between black and white students' perceptions of the medical school learning environment, their academic performances, and their well-being. Acad Med 1989; 64(8):468-473.

18. Mosley TH, Perrin SG, Neral SM, et al. Stress, coping and well-being among third-year medical students. Acad Med 1994; 69(9):765-767.

19. Dunn SV, Burnett P. (1995) The development of a clinical learning environment scale. J Adv Nurs 1995; 22:1166-II73.

20. Al-Zidgali L. Students' approaches to studying at the Institute of Health. Sciences, Sultanate of
Oman. Masters of Medical Education Dissertation. Centre for Medical Education, Dundee University, Scotland; 1999.

2I. Al-Qahtani MF. Approaches to study and learning environment in medical schools with special reference to the Gulf countries. PhD thesis, Centre for Medical Education, Dundee University; 1999.

22. Roff S, McAleer S, Ifere OS, Bhattacharya S. A global diagnostic tool for measuring educational environment: comparing Nigeria and Nepal. Med Teacher 200I; 23(4):378-382.

23. Zaini, R. Use of Dundee Ready Education Environment Measure (DREEM) for curriculum needs analysis in the Faculty of Medicine and Medical Sciences at Umm Al-Qura University, Saudi Arabia. Masters Thesis, Centre for Medical Education, Dundee University; 2003.

24. Bassaw B, Roff S, McAleer S et al. Students' perceptive on the educational environment, Faculty of Medical Sciences, Trinidad. Med Teacher 2003; 25(5):522-26.

25. Al-Hazimi A, Zaini R, Al-Hyiani A, et al. educational environment in traditional and innovative medical schools: A study in four undergraduate medical schools, Educ Health, 2004; I7(2): 192-203.

26. Zamzuri, AT, Azli, NA, Roff, S, McAleer S. Students' perception of educational environment in Dental Training College Malaysia, Malaysian Dental J 2003; 25:I5-26.

27. Till, $H$. Identifying the perceived weaknesses of a new curriculum by Mean of the Dundee Ready Education Environment Measure (DREEM) Inventory. Med Teacher 2004; 26(I):39-45.

28. Viera JE, Nunes, MPT, Martins MA. Directing student response to early patient contact by questionnaire. Med Educ, 2003; 37: I 19-1 25.

29. Mayya S, Roff S. Students' perceptions of educational environment: a comparison of academic achievers and under-achievers at Kasturba medical College, India, Education for Health 2004; 17:280-29I.

30. Sobral, DT. Medical students' self-appraisal of firstyear learning outcomes: use of the course valuing inventory. Med Teacher 2004; 26(3): 234-238.

31. Varma R, Tiyagi E, Gupta JG. Determining the quality of educational climate across multiple undergraduate teaching sites using the DREEM inventory. BMC Med Educ 2005; 5 (8):I-4.

32. Jiffry MTM, McAleer S, Fernando S, Marasinghe RB. Using the DREEM questionnaire to gather baseline information on an evolving medical school in Sri Lanka. Med Teacher, 2005; 27:348-352. 